\title{
The Diffusion of Marketing Orientation in a Public Organization: The Case of Nagareyama City
}

\section{地方自治体におけるマーケティング志向の浸透 一 流山市 一}

\section{成蹊大学 経済学部 石井 裕明}

\section{Hiroaki Ishii ${ }^{* 1}$, Taku Togawa ${ }^{* 2}$, Ichiro Inoue ${ }^{* 3}$}

千葉商科大学 商経学部

外川拓
江戸川大学 メディアコミュニケーション学部

井上一郎

\footnotetext{
${ }^{* 1}$ Faculty of Economics, Seikei University, hishii@econ.seikei.ac.jp

${ }^{* 2}$ Faculty of Commerce and Economics, Chiba University of Commerce, t-tgw@cuc.ac.jp

${ }^{*}$ College of Media and Communication, Edogawa University, inouei@edogawa-u.ac.jp
}

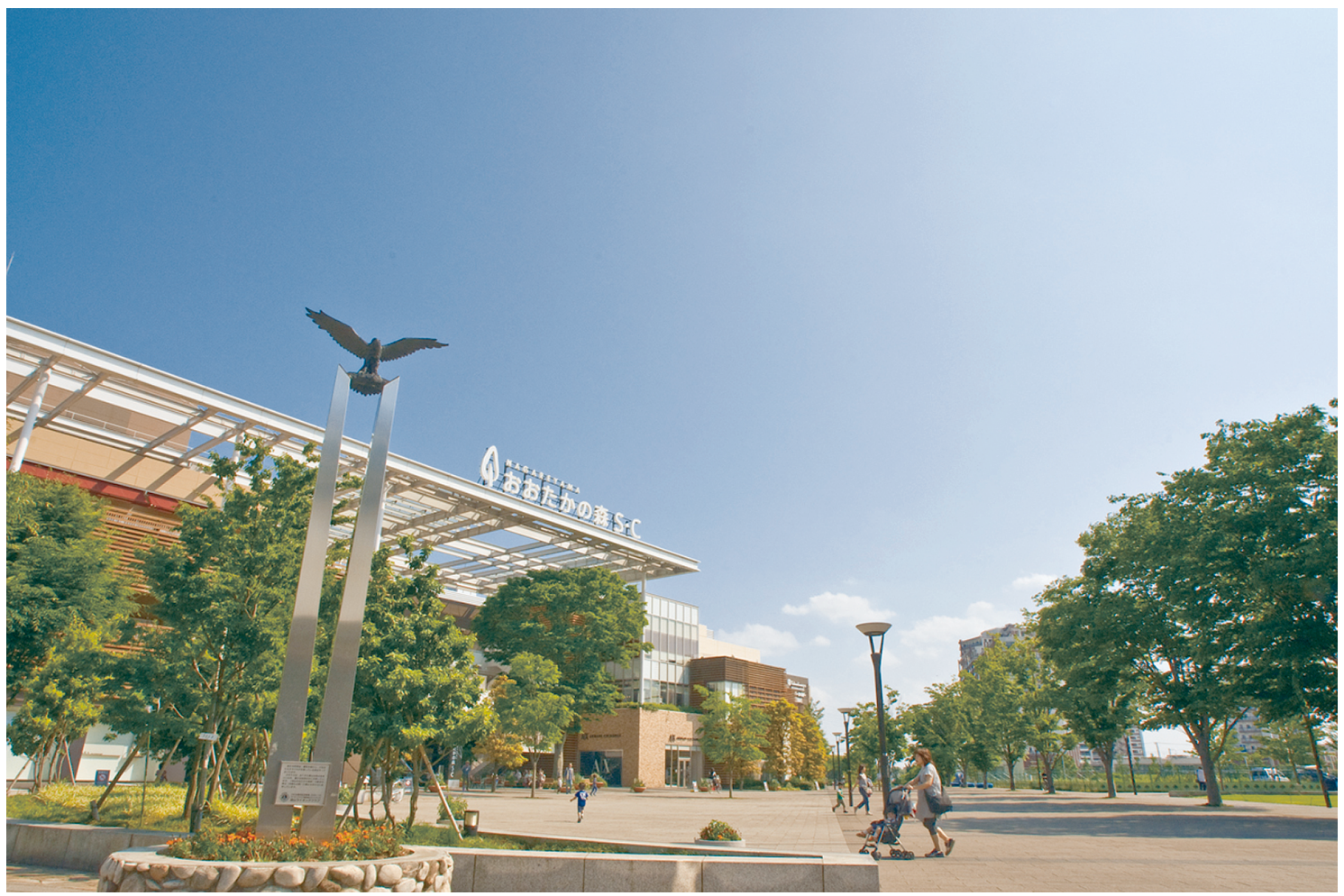

出所：流山市提供。

Abstract : Many researchers and practitioners have discussed the marketing orientation in various organizations. Although marketing orientation in public organizations is a popular theme, only a limited Japanese city offices have given importance to marketing activities. In this article, we focus on Nagareyama City, which has a marketing division and implements many marketing activities. The results of interview surveys indicated that their marketing efforts have contributed to an increase in the population. Our paper indicates the challenges faced by public organizations when 
Marketing Case マーケティングケースーシリーズ 130

implementing marketing activities, the effect of the mayor's emphasis on marketing orientation, and the diffusion of this orientation among public organizations.

Keyword : Marketing in the public sector, Social marketing, Market orientation

要約 : マーケティングが様々な対象に応用できることは古くから指摘されてきた。その中でも, 公共団体への応用は, ソーシャ ル・マーケティングなどとして，しばしば取り上げられるテーマの一つである。その一方, 我が国に目を向けてみると, 本格的 にマーケティングに取り組んでいると考えられる市町村単位の地方自治体はそれほど多くない。そこで本稿では, マーケティン グ課を設置し, 様々なマーケティング活動を展開している流山市に注目した。インタビュ一調査の結果からは, 同市の人口増加 の背景にマーケティング的発想に基づく様々な取り組みが存在することが確認された。また, 自治体組織特有のマ一ケティング を応用する難しさ, トップマネジメントである市長によるマーケティングの強調による効果, 自治体組織にマーケティングを根 付かせるための方策が示唆されている。

キーワード : 公共団体のマーケティング, ソーシャル ·マーケティング, 市場志向

\section{I.「都心から一番近い森のまち」}

東京の秋葉原から 20 分ほど電車に摇られると, 開発 が進む市街地と緑豊かな自然とが混在した風景に出合う ことができる。秋葉原を起点とするつくばエクスプレス 沿線に「南流山」「流山セントラルパーク」「流山おおた かの森」という3つの駅を有する流山市の風景である。 流山市は,「都心から一番近い森のまち」として, 市内外 にPR を続けている。

流山市内を回ってみると，自然と利便性が共存してい ることを実感できる。例えば, つくばエクスプレスの主 要駅の一つである「流山おおたかの森」駅前には, 大規 模ショッピングモールである「おおたかの森 $\mathrm{S} ・ \mathrm{C} 」$ が展 開されており，それを取り巻くようにマンションが立ち 並ぶ。しかしながら，少し足を延ばしてみると，自然豊 かな公園や水辺を見つけることができる。

流山市は，つくばエクスプレスが開業した 2005 年以 降，一貫して人口を増やしている。2010 年と 2015 年に 行われた国勢調査を見比べてみると，流山市の人口は $6.3 \%$ 増加した ${ }^{1)}$ 。この増加率は, 全国の市の中で 7 番 目, 15 万人以上の人口を抱える市の中では最も高い数值 である。また， 2016 年と 2017 年の住民基本台帳人口移 動報告によると，全国で 8 番目に転入者の多い市区町村 でもある 2)。上位の 7 つの自治体はすべて政令指定都市 であるため，それ以外の市区町村では，流山市が最も転
入者の多い自治体となっている。

こうした人口増加において，つくばエクスプレス開業 が大きな影響を与えているのは明白である。しかしなが ら, その成功要因として, 流山市が展開している優れた マーケティング活動が存在することを見落とすべきでは ない。流山市には,「マーケティング課」という市町村単 位の自治体では珍しい部署が存在しているのだ。マーケ ティングに注力しょうという同市の明確な姿勢を見て取 ることが出来る。本レポートでは，流山市を取り上げ， 自治体におけるマーケティング展開について検討して いく

\section{II. 流山市の概要}

千葉県の北西部に位置する流山市は, 人口 189,132 人 (2018 年 9 月), 面積 35.32 平方キロの都市である ${ }^{3)}$ 。流 山一帯は, かつて利根運河や江戸川を利用した水運で栄 え, 江戸時代の中期ごろには，今でも特産品である白み りんを関東一円に出荷していたという。新選組局長の近 藤勇が最後の陣を敷いた場所としても知られている。

現在の流山市が形作られたのは, 1951 年に行われた旧 流山町, 旧新川村, 旧八木村の 3 町村の合併である。合 併当初は「江戸川町」を名乗っていたものの, 東京の江 戸川区と間違われやすいとの理由で，9 か月で「流山町」 に改められたという。その後, 戦後の経済成長とともに, 
流山の人口も右肩上がりで増加していく。常磐線南柏駅 や東武野田線江戸川台駅の開業に合わせて誕生した 「松ヶ丘団地」や「江戸川台団地」など，戸建ての大規模 な団地整備も進められ，合併時に 18,000 人だった人口は 1967 年には 4 万人を超えた。同年, 流山は「町」から 「市」となったが，その後も人口は増え続け，1979 年に は人口 10 万人に達した。

しかしながら， 2000 年ごろに差し掛かると，人口は 15 万人程度で頭打ちの状態が続くようになる。それに加 え，市民の高年齢化が問題視されるようになっていた。 流山市の財源を詳しく見ていくと，住民税における個人 住民税の割合が 9 割に上り，近隣の都市と比べ，法人住 民税の割合が低い。こうした点は，短期的な景気の動き に税収が左右されにくいという強みはあるものの，高齢 化という長期的なトレンドの影響を受けやすいという弱 みもある。2000 年の流山市の年齢別構成においては，50 代の比率が最も高く，17.5\%を占めていた ${ }^{4)}$ 。したがっ て，年齢構成比率の高い 50 代のリタイアが進めば，税 収は落ち込んでしまう。さらに市民の高年齢化は, 福祉 関連支出となって財政に重くのしかかってくる。

新たな住民誘致という面においては，市のイメージが 地味に見えることも課題であった。流山市は松戸市と柏 市という首都圈でも有数の都市に隣接している。2018 年 に市政 75 年を迎えた松戸市は，市の中心である松戸駅 から上野まで 20 分という都心へのアクセスの良さを強 みとして発展してきた。現在の人口は, 489,037人 (2018 年 4 月）である 5)。JR や新京成線の駅周辺には大型商業 施設も出店しており，近隣地域からの買い物客も多い。 柏市は人口 422,385 人 $\left(2018\right.$ 年 4 月）の都市である ${ }^{6) 。}$ 松戸市や流山市に比べ，都心からは距離的に離れるもの の，柏駅周辺の大型商業施設やファッション関連の店舗 が立ち並ぶ裏通りは，週末になると多くの人でにぎわう。

流山市の井崎義治市長は「流山市はベッドタウンのイ メージが強く, 人・モノ・カネが出ていくばかりで, 入っ てくる仕掛けがなかった」と振り返る。また，流山市総 合政策部マーケティング課課長補佐兼マーケティング係 長の大島尚文氏は,「流山市民は休みの日に近隣の松戸市 や柏市に買い物に出かけていく。その一方，松戸市民や 柏市民が流山市に出かけることはほとんどなかった」と
指摘する。例えば,「流山市の子どもたちは, 中学に入学 すると『柏デビュー』をして，遊びに行っていた」のだ という。主要駅やそれに伴う大型商業施設を擁する近隣 の都市に対し，流山市は存在感を発揮できていなかった のである。

以上のような状況を踏まえると, 人口は一定の水準で 推移していたものの, 流山市の将来には厳しい状況が予 想されていた。それだけに，2005 年のつくばエクスプレ 又開業に寄せられる期待は大きかったのである。しかし ながら，つくばエクスプレス開業による沿線の利便性の 向上は，市町村間の競争の激化にもつながると考えられ ていた。人々に流山市の魅力を感じてもらうことができ なければ，沿線の他の駅に人々が流出してしまい，街が 空洞化してしまう可能性もある。つくばエクスプレスの 開業という機会をいかに生かしていくかが，流山市の将 来にとって極めて重要な課題となっていたのだ。

\section{III. 流山市のマーケティング展開}

\section{1. 市長の着任とマーケティングへの注力}

流山市にとって大きな転機となったのは, 2003 年の井 崎市長の就任である。井崎市長はアメリカで都市計画コ ンサルティング会社に勤めていたという経歴を持つ。ア メリカは日本に比べ, 自治体によるマーケティングが盛 しな国であり，井崎市長は「自治体が PR 活動をしない ことがむしろ奇異に感じた」と語っている77。

井崎市長は，人口の伸び悩みと高齢化率の上昇に対処 するためには，マーケティングが必要であると判断し， 流山市のマーケティングを展開する準備に取り掛かる。 目標は子育て世代の誘致である。着任した直後の 2003 年 10 月 1 日, 企画経営課内にマーケティング室を設置 した井崎市長は, 翌年の 4 月 1 日にはマーケティング課 として独立した部署に引き上げた。それと時期を合わせ， 民間企業の経験者を課長に採用し, 従来の市役所業務に 贝われずにマーケティングが展開できる素地を作り上げ ていく。2005 年のつくばエクスプレス開業を前に, 流山 市の魅力を強力に発信していきたいという市長の強い思 いが見て取れる。 
Marketing Case マーケティングケースーシリーズ 130

しかしながら, 同市がマーケティングを展開するため の道のりは，決して容易なものではなかったという。井 崎市長は, 市役所職員が「企業誘致とマーケティングの 違いを理解していなかった」と当時を振り返る。市役所 には馴染みのないマーケティングという考え方を職員達 に理解してもらうために, 市長自らが講師となりマーケ ティングに関する勉強会を開催したこともあった。それ でも一部の職員から「行政がマーケティングをする必要 があるのか」といった反発の声が上がったという。

その様な状況下ではあったが, 流山市のマーケティン グ戦略の骨子が組み立てられていく。流山市にとっての 強みの一つは, 都心への近さである。つくばエクスプレ スが開通すれば，都心まで約 20 分でアクセスできる。 こうした点は都内に勤め先を持つ若い世代にも大きな魅 力となるはずである。

2003 年当時, 夫婦やカップルのライフスタイルを示す

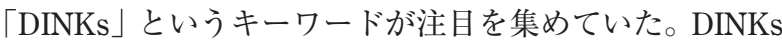
とは，「Double Income No Kids」の頭文字を並べたもの で，共働き夫婦が意図的に子供を持たないライフスタイ ルのことである。DINKs は一般的に所得が高く，彼らを 誘致できれば租税収入の向上も期待できる。しかしなが ら，流山市が抱えている問題点の一つである市民の高年 齢化を考えると, DINKs の誘致には課題があった。DINKs カップルが年を重ね，退職していくことになると，税収
が減るだけでなく福祉のための費用も必要になるため, 法人住民税による税収が少ない流山市においては収支の バランスが崩れてしまう恐れがあったのである。

そこで流山市は「DEWKs」と呼ばれる子育て世代を ターゲットに据えた。DEWKs とは,「Double Employed With Kids」のことで，夫婦ともに仕事を持ちながら子育 ても行うライフスタイルのことである。流山市には, ゆっ たりした戸建て住宅が多く, 緑化資源も豊富に存在して いる。こうした点が, 子育て世代に強く訴えられると考 えたのである。実は，DINKs をターゲットとした場合よ りも，DEWKs をターゲットにした場合の方が，子育て 支援などの施策に力を注がなくてはならず，短期的には コストがかかるという。しかしながら，大島氏は，「長期 的な視点から DEWKs をターゲットにしている」と語る。 親世代が退職したとしても, 子供世代を流山に定着させ ることができれば，長期的な財政の健全化に寄与できる と考えられるのである。

都心へのアクセスの良さと, 緑豊かで良質な住環境を 子育て世代に訴求する。これが流山市におけるマーケティ ング戦略の最も基本的な構造となっている。そのために 設定された市のイメージが, 冒頭でも紹介した「都心か ら一番近い森のまち」というフレーズなのである。

\section{図 2 流山市の人口の推移}

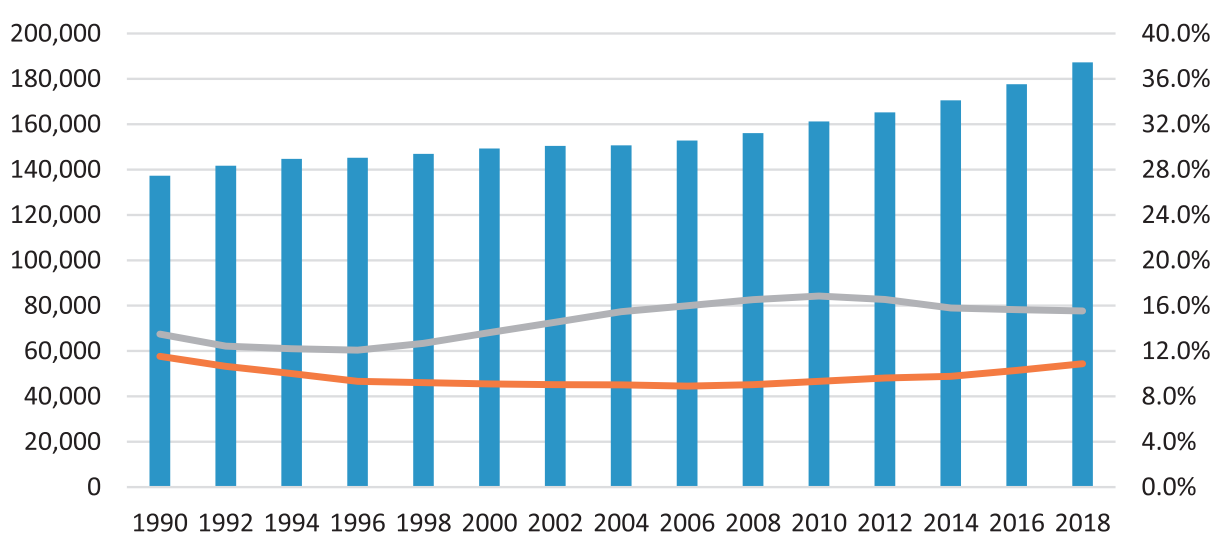

総人口 $\quad$ 0 9歳比率 $\quad 30 \sim 39$ 歳比率

出所） Nagareyama City（2018c）より筆者作成 


\section{2. ブランドイメージの確立に向けた取り組み}

首都圈近郊で住まいを探している子育て世代に，流山 市を選択肢の一つにしてもらう。それこそが流山市がま ず初めに達成しなくてはならないマーケティング目標で あった。井崎市長の就任当時, 首都圈近郊における流山 市の知名度は極めて低く，住宅購入を考えている子育て 世代が選択肢として流山市を思い浮かべるのは難しい状 況であった。しかしながら，知名度の低さが功を奏した 部分もある。ターゲットである子育て世代において，流 山に対するイメージが白紙だったのである。つまり，今 後のマーケティング展開次第では, 好ましいブランドイ メージを構築していくことが可能であった。流山市の知 名度向上と好ましいブランドイメージの確立を目指し， 流山市のマーケティング活動は展開されていく。

2005 年の春には, その後の流山市のブランド戦略に大 きく影響を与える決定も行われた。つくばエクスプレス の開業を前に，流山市に開業が予定されていた 3 つの駅 のうち，2つの駅の名称を変更したのである。「流山中 央」と「流山運動公園」となる予定であった駅名を，そ れぞれ現在の名称である「流山おおたかの森」と「流山 セントラルパーク」に変更した。ブランドイメージが定 着していない流山市にとって，都市の顔ともなる駅に独 自性のある名称を採用できたのは，その後のマーケティ ング戦略やブランド戦略において極めて重要であった。 井崎市長は, この駅名の変更について, 流山市のブラン ド戦略の出発点であったとも指摘している ${ }^{8)}$ 。マンショ ン開発業者をはじめとする関係者に対しても，独自性の ある駅名の採用が大きな影響を与えたことは想像に難く ない。また「森のまち」をアピールしていく上では,「お おたかの森」という駅名の採用が大きな弾みとなったは ずである。

もちろん流山市のブランド戦略を支えるのはイメージ だけでない。たとえば，良質な住環境を作り，守ってい くために，江戸川台や松ヶ丘など，流山市の代表的な住 宅地の宅地分割を地区計画で制限している。一般的に, 宅地の分割制限をすると，一区画あたりの価格が高止ま りしてしまうため，土地の売れ行き自体は芳しくなくな り，地価の下落につながるリスクもある。しかしながら 井崎市長は,「宅地分割して小さな開発をしやすくする
と，住環境としてのクオリティが低下するため，うまく いくのは数年間だろう」と指摘する。逆に「宅地分割を せずに良質な住環境を維持すると，そういう環境を求め る人が買いに来る。短期的に土地の価格は下がってしまっ たとしても，長期的に見れば，価值を維持できるはずだ」 と話してくれた。実際，市内にある小学校 16 校の多く は在籍生徒数が増加傾向にあるという。長期的な視点か ら良質な住環境を守ってきたからこその成果であろう。

さらに，流山市は子育て世帯に向けた積極的な施策も 展開している。子育て世帯を強力にバックアップする「駅 前送迎保育ステーション」というサービスは, 待機児童 対策として 2007 年に作り上げられた。このサービスは, 市内の主要駅である流山掞扔たかの森駅と南流山駅にあ る駅前送迎保育ステーションと市内の各保育所（園）を バスでつなぐ。流山市の面積は約 $35 \mathrm{~km}^{2}$ であり，松戸市 (約 $\left.61 \mathrm{~km}^{2}\right)$ や柏市（約 $114 \mathrm{~km}^{2}$ ) といった近隣の都市に 比べて面積が狭く, 交通渋滞の少ない特徴を生かしたサー ビスである。一時預かり施設を併設しているため，親は 出勤前に駅前の施設に子供を預け, 帰りに迎えに行けば よい。一回 100 円の利用料はかかるものの, 都心に出勤 する親達にとって，駅前で子供の送迎が完結できるのは 極めて利便性が高い。待機児童の問題もあり，近年では， 兄弟姉妹が別々の保育園に通うケースも珍しくない。送 迎保育ステーションのサービスを利用すれば，別々の保 育園に通う兄弟姉妹の送迎も一か所で済むため，共働き をする親たちにとっては大きな味方となっている。その 他にも, 認可保育園の新増設や市内全中学校への外国語 指導助手の配置など，子育て世代を意識した取り組みに カが注がれている。

\section{3. ターゲットにおける知名度向上を目指したプロモー ション戦略}

ターゲットに向け良質な住環境を訴求できる素地を整 えながら, 流山市は知名度向上を目指した取り組みを進 めていく。2010 年には,「母になるなら, 流山市。」とい うキャッチコピーの交通広告が都心のターミナル駅など で展開された（図 3)。こうしたプロモーション展開は, 地方の住宅都市の取り組みとしては極めて珍しい。広告 の内容においては, 若い夫婦と子供の写真が掲載されて 
Marketing Case マーケティングケースーシリーズ 130

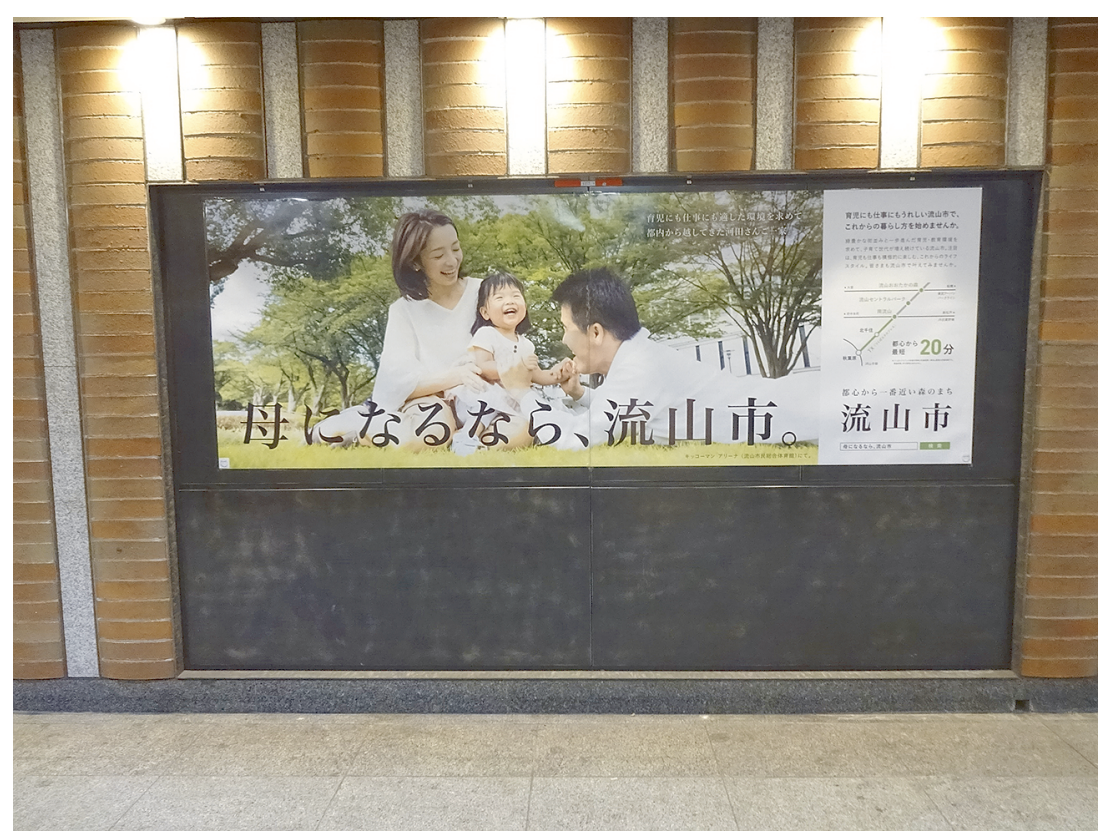

出所 : 流山市提供

いるが，細かい説明などはほとんど掲載されていない。 大島氏は,「細かい説明調の宣伝文句は, 逆に広告として の訴求力を弱める。首都圈で住宅購入を検討している層 に少しでも流山を知ってもらい, 選択肢の一つになるこ とが重要」という。さらに，「詳細な情報は，HP などを 見てもらえばわかってもらえる。それよりも流山市のイ メージを定着させたい」と続ける。広告に登場する親子 は，全て流山市に居住している家族である。第一回目の 広告には，横浜市青葉区など，流山以前の居住地を限定 したモデル家族を探し出し，良質な住み替えのイメージ を訴求した。実際に流山で生活している家族をモデルと して採用することで，言葉では伝えきれない「物語」を 感じてもらいたいのだという。

また，市外から人々を流山に呼び込むイベントの開催 も積極的に進められている。例えば, 2011 年から流山お おたかの森駅前や南流山駅前で開催されている「森のマ ルシェ」というイベントは，5月に行われる「グリーン フェスティバル」，8月に行われる「森のナイト・カ フェ」, 11 月に行われる「ハーヴェスティバル」, 12 月 に行われる「森のマルシェ・ド・ノエル」などで構成さ
れる。もちろん，イベントに多くの人々を呼び込むため には，目新しいものを積極的に取り入れなければならな い。例えば, 2011 年 12 月の「森のマルシェ・ド・ノエ ル」では, いち早くプロジェクション・マッピングを取 り入れたショーを展開した。プロジェクション・マッピ ングは, 2012 年に東京駅の新駅舎でも行われることで大 きな話題となったが, それに先立って実施されていた流 山市のイベントは, 関東での先行事例として様々なメディ アに取り上げられたという。その結果, その翌年のイベ ントには, 12 月 22 日と 23 日の二日間で 27,000 人の来 場者があり，そのうちの $60 \%$ 以上が市外からの来場者で あった。

こうしたプロモーションに対する流山市の姿勢は一貫 している。例えば, 上述した広告は, 流山市を走る鉄道 の沿線ではなく，首都圈の駅や鉄道に掲出されている。 というのも, プロモーションのターゲットは流山市を知 らない首都圈の人々であり, 流山市近郊の人々ではない からである。一般的に市の広告と聞くと, 市内の駅や路 線に掲出されている印象を抱くが, 流山市にとって既に 居住している人々にイメージを訴求することが本来の広 


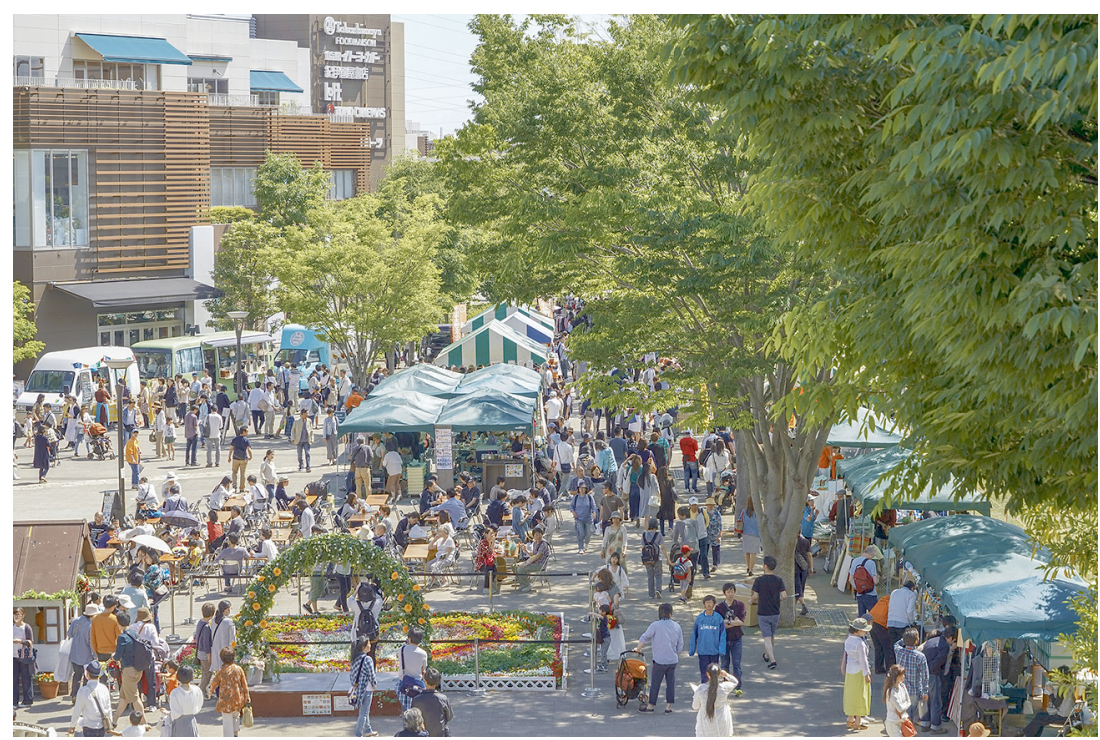

出所：流山市提供

告目的ではない。流山市はあくまで「将来の住民」に流 山市を知ってもらい，望ましいイメージを抱いてもらう ことに徹したのである。

また，自治体が行うイベントにおいては，市内の参加 業者に打ける商業的な成果や，全体の参加者数などが重 視されることも多いが，流山市では単なる来場者数だけ でなく，市外からの来場者の比率からも判断していると いう。魅力的なイベントは，市外の人が流山市を知り， 体験するには絶好の機会となる。しかも，それぞれのイ ベントについて,「成功したら同じことをやらない」こと を基本としている。井崎市長は,「現在ではイベント来場 者のうち 4 割から 5 割の人が市外の人になっている。就 任当初には考えられない。」話してくれた。各イベント の来場者数も年を追うごとに増加してきている。新たな イベントを仕掛け，市外からの来場者を集めることで, 流山市の知名度とブランドイメージの向上が図られてい ることが分かるだろう。

\section{IV． 自治体によるマーケティング展開の背景}

\section{1. 組織としての共通認識の醸成}

ここまで確認してきた通り，流山市はターゲットや自 らのポジショニングを明確に設定したうえで，それに合 わせた施策を展開している。こうした一連の取り組みは, マーケティングにおける定石ともいえるだろう。しかし ながら，上述した通り，自治体組織によるマーケティン グ展開は，決して容易なものではない。

2009 年, 流山市マーケティング課の中にシティセール ス推進室が設置され，民間から室長と報道官が採用され た。この組織改編によって, マーケティング課は従来か らの公務員従事者 2 名, 民間経験者 3 名, 臨時職員 1 名 の 6 名体制となる。こうした組織体制について，大島氏 は，「民間企業では当たり前のようなことでも，自治体組 織では強い反発が起きてしまうこともある。民間経験者 による発想を市役所の文化になじませていくことができ る。」と指摘する。2011 年の流山市シティセールスプラ ン策定の際には, まさに自治体組織にマーケティング発 想をなじませる工夫が施されている。 
Marketing Case マーケティングケースー シリーズ 130

2011 年に策定された第 I 期のシティセールスプラン は，それまでも進められてきた流山市のマーケティング の考え方を改めて明文化したものである。流山市総合政 策部マーケティング課シティセールス推進室室長の筒井 秀夫氏は，プランについて「実は他の自治体が策定して いるものと大差はない」と述べながらも,「唯一違うので あれば, DEWKs をターゲットとしていることを掲載し た点」と続ける。

ターゲットを明確に設定し，それに適した戦略を展開 していくことは，民間企業におけるマーケティングの出 発点ともいえる。しかしながら, 自治体組織においては, ターゲットの設定自体が難しいこともあるという。例え ば，若い世代をターゲットに定めたと明文化することで, 「全世代から得られた税金を特定の世代だけに使うのか」 「他の世代を無視するのか」などといった批判的な声が上 がる可能性があるのだ。2011 年に策定されたシティセー ルスプランにおいて, DEWKs を住民誘致のためのプロ モーションのターゲットとして明記した点も,「(当時と しては）許されるギリギリの範囲だろう」と大島氏は振 り返る。実は, このシティセールスプランの素案は, マー ケティング課内のみで策定されたという。素案策定前に 他部署や外部に意見を求めると, ターゲットの明記につ いて, 様々な意見が寄せられることは容易に想像がつく。 その代わり，自治体として受け入れられる表現を従来か らの公務員メンバーを中心に熟考したのだという。民間 企業で培われた発想を自治体組織で活用していくために は, 絶妙なバランス感が必要なのである。

こうして策定されたシティセールスプランであるが, プロモーションのターゲットを DEWKs として明記した ことが，流山市役所全体に与えた影響を過少評価するべ きではない。民間企業においても，ブランド・ビジョン などの策定に当たっては，明文化による関係者間の意識 の共通化や一貫したマーケティング戦略実現などのメ リットが指摘されている。流山市においても，住民誘致 のターゲットとして, DEWKs が意識されていたのは, シティセールスプラン策定前からである。多くの市役所 職員も DEWKs を呼び込みたいことは暗黙のうちに意識 していたとは考えられる。しかしながら，それが明文化 されることによって，市役所組織全体として意識が共有
されやすくなったことは間違いない。明文化され，組織 全体に共有されることで, DEWKs 誘致への機運がより 一層高まったと考えられる。

\section{2. マーケティング実現のためのしくみづくり}

流山市の躍進を支えているのは，民間企業で行われて いるマーケティングの発想を巧みに自治体組織に取り入 れた点であろう。上述した通り, マーケティングの骨子 でもあるターゲティングの考え方は，公平性を重視する 自治体組織が取り入れにくい面もある。例えば，流山市 が展開している広告について，「市民の税金で作成したポ スターを首都圈に掲出して, 市民が見られないのはおか しい」といった声や, 首都圈からのアクセスを重視して いるイベントについて,「市内その他のエリアで展開しな いのは不公平だ」といった声も上がるという。しかしな がら, 流山市はこうした批判的な声を一つ一つ乗り越え てきている。

筒井氏は「近年, 多くの市や町の職員の方が視察にい らっしゃる。他の組織で似たような取り組みが展開され てもおかしくない」と指摘する。しかしながら, 表層的 な取り組みだけを他の自治体が導入しようと思っても， うまくはいかないだろう。流山市におけるマーケティン グの導入においては，組織的な要因が強く関わっている と考えられるからである。

一つの大きな要因は, トップマネジメントである市長 によるマーケティングの強調である。Jaworski and Kohli （1993）は, トップマネジメントによって市場志向が提 唱されると, 組織の市場志向にプラスの影響があること を実証している。また, Cervera, Mollá, and Sánchez （2001）では，市長による市場志向の強調が取り上げら れており，公共機関における応用性も確認されている。 民間出身の井崎市長がマーケティングを理解し，それを 推し進めようとしている点は, 流山市のマーケティング において大きな影響を及ぼしていると考えられる。特に， マーケティング課という独立した組織を設けたのは，市 役所内外に向けてマーケティングを推し進めていくとい う強いメッセージにもなる。また，「室」ではなく「課」 とすることで, 市長自身がマーケティング課の活動に直 接的に関与しやすくする側面もあったという。市長がマー 
ケティング課の活動に継続的に関わっていくことで, 組 織内外にマーケティングの重要性が強調されやすかった と考えられる。

また，マーケティング課が市役所組織において巧みな バランス感覚を持って組織されていることにも注目すべ きであろう。この点について大島氏は「民間から職員を 採用すればうまくいくわけではない」と断言する。民間 から職員を採用すれば，多様性が高まり，創造的な発想 が生まれやすくなるかもしれない。その一方で，あまり にも異なる価値観の職員だけで施策が作り上げられてし まうと, 部署間のコンフリクトが強まり, マーケテイン グ施策の実施は難しくなってしまうだろう。「民間経験者 から出される新たな発想の尖った部分を残しつつ，行政 職員が市役所の文化でも受け入れられるようにしていか なくてはならない」と大島氏は指摘する。バランス良く 組織されたマーケティング課が市役所内で様々な活動を 展開することで，マーケティング課以外の部署にもマー ケテイング的な発想やマーケティング戦略の方針が浸透 していきやすくなる。シティセールスプランに見られる 通り，自治体の組織文化の中でも受け入れられる形を目 指した点も流山市のマーケティングの成否を分けたポイ ントとなっているだろう。

マーケティング活動の柱の一つにイベントが据えられ ていた点も注目すべきである。イベントは，ブランドの 世界観を伝達する重要なマーケティング・コミュニケー ション手法であるだけでなく，主催者と顧客との直接的 なインタラクションが生まれる場ともなる。マーケティ ング課が開催するイベントには，課を越えて様々な職員 が参加し，イベント来訪者との直接的な交流が生まれた という。井崎市長は「イベントで楽しそうにしている市 民や来訪者の顔を見ることで, 職員の意識が徐々に変わっ ていった」と話してくれた。目の前の仕事に集中すると， 顧客を見失いがちになるのは民間企業におけるマーケ ティングに扔いてもしばしば指摘される点である。組織 にマーケティング的な考え方を浸透させていく上で，顧 客と職員との接点づくりは重要な役割を果たしたと考え られるだろう。

\section{V. 流山市の現在}

2005 年 4 月に 150,910 人だった流山市の人口は, 2018 年 4 月には186,863 人にまで増えている。それに加えて, 30 代の子育て世代と 0 歳 9 歳の子供世代の割合が増加 している9 ${ }^{9}$ ささらに，転入者に行っているアンケートに よると，流山市以外に候補としていた転居先がなかった

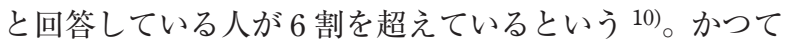
の「『流れ流れて流山』と多くの他の候補地の中から消極 的な理由で選ばれていた (井崎市長)」という状況が，大 きく改善していることが分かる。

2016 年には 2011 年に策定されたシティセールスプラ ンに続き，第 II 期のシティセールスプランが策定され た。具体的な内容を見てみると, 第 II 期のシティセール スプランにおいては知名度やブランドイメージの向上に とどまらず，「熱烈ファン」や「アンバサダー」の創出な ど，ブランドとしての流山と人々とのリレーションシッ プ深耕が目標として揭げられている。さらに一部では, こうした「熱烈ファン」や「アンバサダー」と協同した 取り組みも進められ始めているようだ。

2018 年に 14 回目を迎えるオープンガーデンイベント は，「ながれやまガーデニングクラブ“花恋人”」が主催し ている。このガーデニングクラブは流山市が主催したガー デニングフォトコンテストへの応募者を中心に設立され ており，市と住民とが協働しながらコミュニティやイベ ントが創造されているのが分かる。2017 年のオープン ガーデンイベントには, 全国から 3 日間で 16,000 人もの 来場者があり，現在のガーデニングクラブのメンバーに は，このオープンガーデンをきっかけに流山へと転居し てきた人もいるという11)。

また, 2016 年 5 月 11 日には, 南流山駅から徒歩数分 の住宅地に子育て女性向けのワーキングスペース Trist が 開業した。流山市在住の 2 児の母でもある尾崎えり子氏 が開業した Trist は, 尾崎氏の「出産後に地元で働ける場 が必要」という思いから生まれたという（Kimura, Sakamaki, \& Jibu, 2017)。流山市は，「流山市商店街空き 店舗有効活用等事業補助金」を使って, 初期費用 100 万 円などの支援を行っている（Ishii, 2016）。流山市が推し 
Marketing Case マーケティングケースー シリーズ 130

進める子育て世代の誘致に呼応するように，市民の側か らも魅力的な取り組みが生まれ始めていることが分かる。

井崎市長は流山市の魅力について「面白いことをやろ うという意識と意欲の高い市民が多いこと」としたうえ で,「市に提案したら受け止めてくれるという信頼関係を 築いたうえで，『ないもの』や『欲しいもの』を市民自身 が作り上げるのを市が応援していく形にしていきたい」 と語ってくれた。流山市の方向性に共感した「熱烈ファ ン」や「アンバサダー」との協働がうまくできれば，魅 力的な施策がさらに生み出される可能性もある。

\section{VI. 今後の課題}

着実に人口を増加させている流山市であるが, 課題が ないわけではない。一つは, つくばエクスプレス沿線の 市町村競争の激化である。例えば, 2005 年の段階で 53,700 人であった守谷市の人口は, 2018 年 4 月には 66,598 人 に，40,174 人だったつくばみらい市の人口は 51,570 人ま で増えており，増加率では流山市を上回る ${ }^{12) 。 こ う し た ~}$ 人口増加は, 八潮市, 三郷市, 柏市, つくば市などでも 確認でき，沿線での住民誘致の競争は激化している。流 山市の取り組みが注目されれば，近隣の市町村でも類似 した取り組みが行われる可能性もある。今後はこれまで 以上に新たな取り組みへの挑戦が必要となってくるだ ろう。

井崎市長は交流人口の増加を課題として挙げる。高齢 化が進む日本においては，定住人口の長期的な増加を望 むことは難しい。その際には，交流人口の確保による地 域の活性化が重要になるからである。現在でもイベント などの効果により, 流山市における交流人口は増加して きている。それに加えて, ッーリズムにも注力している という。利根運河や流山本町など, 歴史的な背景を有す る地域を中心に，今後さらに質を重視したツーリズム需 要を開拓できるかが課題となるだろう。

また,「熱烈ファン」や「アンバサダー」との協働や共 創に向けた取り組みも求められるだろう。転入者に話を 聞いてみると，流山市在住の「熱烈ファン」や「アンバ サダー」などによるクチコミの影響を確認することが出
来るという ${ }^{13)}$ 。実際， 2018 年 5 月に行われたグリーン フェスティバル来場者のうち流山市在住の人を対象に, 流山市を転居先として推奨したいかを尋ねたところ， 3

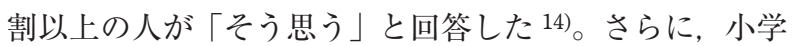
生が同居している回答者においては,「ややそう思う」を 合わせると 7 割に達する。調査人数が多くなく参考值で はあるものの，彼ら／彼女らによる情報発信を可視化し， それらを統合することが出来れば, より強固な波及効果 を生み出すことが出来るはずである。このことは, 井崎 市長が「流山市第 2 期シティセールスプラン」の中で掲 げている価值提案コンセプト「市民の知恵と力が活きる まち」とも合致するだろう 15)。

さらに，流入してきた DEWKs 世帯の子供たちをいか にして流山市に定着させるかも課題になってくる。 DEWKs 世帯をターゲットとした目的の一つは子供世代 の流山への定着である。今後はどのようにして，こうし た子供世代に愛着を持ってもらい, 流山市に長期的に居 住してもらうかが重要である。第 II 期シティセールスプ ランに記載されている「シビックプライド」をいかに強 固に釀成できるかがポイントとなる。

\section{VII. 結びにかえて}

井崎市長は,「戦略的市政経営」という言葉を使いなが ら, 地域の可能性を見据えて長期的に自治体を導いてい く重要性を説明してくれた。従来の自治体経営は, どち らかというと「モグラたたき的」であり，顕在化したニー ズに対処している側面が強かったという。しかしながら， そうした対応では地域としての付加価值を高めにくい。 「自治体の未来は変えられる」という強い信念を持ち, 長 期的で具体的な目標設定をしながら組織を導き，市民の 潜在的ニーズにも対応していくことで, 地域に付加価值 が生み出されるのである。

また，大島氏は「市役所の職員は優秀な人が多い。そ れぞれに非常にいいサービスを追求している。ただ，伝 え方が上手でない場合が多い」と指摘する。マーケティ ングを展開する上では，製品だけでなく，流通，価格， プロモーションを総合的に考え，適切な組み合わせを検 
討することで顧客価值を高めていくことが求められる。 大島氏の指摘を参考にすると，行政組織に扔いて，製品 やサービスの部分は十分に練り上げられているのかもし れない。しかしながら, 他のマーケティング要素が不十 分であるとするならば，それらを検討し，巧みに組み合 わせることで，市民にとって価值あるサービスを展開で きる可能性がある。

井崎市長は就任以来, 職員に「誰に向けて仕事をして いるのか」と問い続けてきたという。顧客志向はまさに マーケティングの本質である。日本の行政組織における マーケティングの応用事例は，それほど多くない。顧客 に向けて適切に施策を組み合わせるというマーケティン グ的な発想や視点の活用は，人々のより良い生活の実現 の一助となるかもしれない。

\section{謝辞}

本ケースの執筆にあたっては, 2017 年 12 月 12 日に井 崎義治流山市長， 2013 年 8 月 15 日に流山市役所総合政 策部 筒井秀夫氏（マーケティング課シティセールス推進 室室長), 大島尚文氏 (マーケティング課課長補佐兼マー ケティング係長）にインタビューにご協力をいただきま した(役職名は取材当時のもの)。またインタビューの実 現に当たっては，江戸川大学メディアコミュニケーショ ン学部残間義和特任教授にご尽力いただきました。ここ に記して厚く感謝申し上げます。

\section{注}

1） Statistics Bureau of Japan（2016）に基づき算出。

2) Nagareyama City（2018b）より。

3） Nagareyama City（2017）抽よび Nagareyama City（2018d） より。

4) Nagareyama City（2018c）から算出。

5) Matsudo City (2018) より。

6) Kashiwa City (2018) より。

7） Umesaki（2013）のインタビュー記事より。

8） Umesaki（2013）のインタビュー記事より。

9) Nagareyama City (2018c) から算出すると, 全人口に占め る 0 歳 $９$ 歳と 30 歳〜39 歳の割合は, 2003 年はそれぞれ $9.05 \%$ と $15.00 \%$ であったのに対し， 2018 年は $10.87 \%$ と $15.54 \%$ へと増加している。

10) Nagareyama City（2018a）より。

11） 2017 年 12 月 12 日に行われた筆者らによる井崎市長へのイ ンタビューによる。

12） Moriya City（2018）および Tsukubamirai City（2018）
13） 2017 年 12 月 12 日に行われた筆者らによる井崎市長へのイ ンタビューによる。

14） 2018 年 5 月 4 日にグリーンフェスティバル会場で行われた 江戸川大学エドアドおよび井上ゼミ学生の調査による。有 効回答数 58。なお, 調査結果は Edogawa University Inoue Seminer（2018）でも報告されている。

15） Nagareyama City（2016）より。

\section{References}

Cervera A., Mollá, A., \& Sánchez, M. (2001). Antecedents and consequences of market orientation in public organisations. European Journal of Marketing, 35(11/12), 1259-1288.

Edogawa University Inoue Seminer (2018, May). Kуоиi no tennуии tyoukasuu wo jitugen shita Nagareyama-shi no marketing senryaku. Poster Presented at Creative Forum 2018 of Japan Academy of Advertising, Nagoya, Japan（江戸川大学井上ゼミ ナール (2018). 「脅威の転入超過数を実現した流山市のマー ケティング戦略と今後の展開について」, ポスターセッショ ン発表資料, 日本広告学会クリエーティブフォーラム 2018) (In Japanese)

Ishii, K. (2016, May 19). "Haha ni narunara, Nagareyama-shi," Tsugi no itte ha kosodate josei no koyou sousyutu. Retrieved from http://www.nikkeibp.co.jp/atcl/tk/15/433782/051600335/ （石井和也（2016）。「『になるなら, 流山市』, 次の一手は 子育て女性の雇用創出」) (In Japanese)

Jaworski, B., \& Kohli, A. (1993). Market orientation: Antecedents and consequences. Journal of Marketing, 57(3), 53-70.

Kashiwa City (2018, May 7). Maitsuki joujuu jinko. Retrieved from http://www.city.kashiwa.lg.jp/soshiki/020800/p019718.html (柏 市（2018）。「毎月常住人口」) (In Japanese)

Kimura, A., Sakamaki, T., \& Jibu R. (2017). Nagareyama-shi: Hito ga deteiku machi kara haittekite sumitudukeru machi he. Hitotsubashi Business Review, 65(3), 166-177（木村篤, 酒巻 徹，治部れんげ (2017)。「流山市：人が出ていく街から入っ てきて住み続ける街へ」『一橋ビジネスレビュー』65(3), 166-177) (In Japanese)

Matsudo City (2018, May 9). Matsudo-shi no jinko doutai. Retrieved from https://www.city.matsudo.chiba.jp/profile/jinkoutoukei/jinkou/ jyoujyu/jinkoudoutai.html（松戸市 (2018).「松戸市の人口 動態」) (In Japanese)

Moriya City (2018, May 2). Heisei 28 nen (2018 nen) no jinko. Retrieved from https://www.city.moriya.ibaraki.jp/shikumi/ statistics/statistics/2018zinkou.html（守谷市（2018）. 「平成 30 年 (2018 年) の人口」) (In Japanese)

Nagareyama City (2016, December 28). Nagareyama-shi city sales plan 2nd. Retrieved from http://www.city.nagareyama.chiba.jp/ _res/projects/default_project/page_001/006/913/city-2teisei2. pdf（流山市（2016)。「流山市 第 II 期シティセールスプラ ン」) (In Japanese)

Nagareyama City (2017, April 1). Nagareyama-shi no gaiyo. Retrieved from http://www.city.nagareyama.chiba.jp/information/ 1006883/1006884/1006885.html（流山市（2017）。「流山市の 概要」) (In Japanese)

Nagareyama City (2018a, February 16). H29 tennyuu-sya anketo 
Marketing Case マーケティングケースー シリーズ 130

syukei. Retrieved from http://www.city.nagareyama.chiba.jp/ _res/projects/default_project/_page_/001/009/954/ank-h29.pdf （流山市（2018a）。「H29 転入者アンケート集計」）(In Japanese)

Nagareyama City (2018b, February 16). Marketing ka. Retrieved from http://www.city.nagareyama.chiba.jp/section/1009951/ 1009954/index.html（流山市 (2018b).「マーケティング課」) (In Japanese)

Nagareyama City (2018c, April 11). Nenrei betsu jinko no suii. Retrieved from http://www.city.nagareyama.chiba.jp/information/ 1008422/1008423/1008453.html（流山市（2018c）。「年齢別 人口の推移」) (In Japanese)

Nagareyama City (2018d, May 18). Nagareyama-shi no joju jinko. Retrieved from http://www.city.nagareyama.chiba.jp/information/ 1008422/1008423/1008457.html（流山市（2018d）。「流山市 の常住人口」) (In Japanese)

Statistics Bureau of Japan (2016, December 16). 2015 Population Census. Retrieved from http://www.stat.go.jp/data/kokusei/ 2015/kekka.html（総務省統計局（2016）。「平成 27 年国勢調 査」) (In Japanese)

Tsukubamirai City (2018, May 1). Shi no jinko. Retrieved from https://www.city.tsukubamirai.lg.jp/viewer/info.html?id=5\&g= 545 (つくばみらい市（2018）。「市の人口」）(In Japanese)

Umesaki, K. (2013, August 2). 30dai jinko kyuuzo! Nagareyam-shi "Itan" no machi dukuri: Marketing ga areba chiho toshi ha yomigaeru. Retrieved from https://toyokeizai.net/articles/-/ 16818 （梅崎恵司（2013）。「30 代人口急増！流山市, “異 端”の街づくり：マーケティングがあれば，地方都市はよみ がえる!」) (In Japanese)

\section{石井 裕明（いしいひろあき）}

成蹊大学経済学部准教授。早稲田大学商学部を卒業後, 同 大大学院商学研究科修士課程および博士後期課程へ進学。 博士(商学)。千葉商科大学サービス創造学部専任講師, 准 教授を経て, 2015 年より現職。専門は, 消費者行動, マー ケティング。

\section{外川拓（とがわ たく）}

千葉商科大学商経学部准教授。東海大学政治経済学部を卒 業後, 早稲田大学大学院商学研究科修士課程および博士後 期課程へ進学。博士(商学)。千葉商科大学商経学部専任講 師などを経て，2016 年より現職。専門は, 消費者行動, マーケティング。

\section{井上一郎（いのうえいちろう）}

江戸川大学メディアコミュニケーション学部教授。明治学 院大学経済学部卒業, 早稲田大学大学院商学研究科修士課 程修了。旭通信社 (現 ADK), 宣伝会議 (月刊販促会議編 集長), アサッーディ・ケイ (第 1XC 局長ほか), 江戸川大 学准教授を経て 2018 年より現職。専門は, マーケティン グ，統合マーケティング・コミュニケーション。 